\title{
Environmental Health Status of Some Aquatic Ecosystems in Badagry Division, Lagos, Nigeria
}

\author{
Mekuleyi Gabriel Olarinde ${ }^{1, *}$, Anetekhai Martins Agenuma ${ }^{1}$, Aderinola Oluwatoyin Joseph ${ }^{2}$, \\ Adu Abosede ${ }^{3}$ \\ ${ }^{1}$ Department of Fisheries, Faculty of Science, Lagos State University, Lagos, Nigeria \\ ${ }^{2}$ Department of Zoology and Environmental Biology, Faculty of Science, Lagos State University, Lagos, Nigeria \\ ${ }^{3}$ Department of Botany, Lagos State University, Ojo, Nigeria \\ Email address: \\ gabrielmekuleyi@gmail.com (M. G. Olarinde), anetekhaimartins@gmail.com (A. M. Agenuma), \\ oluwatoyin.aderinola@lasu.edu.ng (A. O. Joseph), adu_bose@yahoo.co.uk (A. Abosede) \\ ${ }^{*}$ Corresponding author
}

\section{To cite this article:}

Mekuleyi Gabriel Olarinde, Anetekhai Martins Agenuma, Aderinola Oluwatoyin Joseph, Adu Abosede. Environmental Health Status of Some Aquatic Ecosystems in Badagry Division, Lagos, Nigeria. International Journal of Ecotoxicology and Ecobiology.

Vol. 4, No. 4, 2019, pp. 93-102. doi: 10.11648/j.ijee.20190404.13

Received: October 10, 2019; Accepted: November 14, 2019; Published: December 4, 2019

\begin{abstract}
The status of Agboju, Ajegunle, Topo and Gbaji water bodies in Badagry Division of Lagos State, Nigeria was evaluated between April and November 2018 in order to determine the suitability of the ecosystem to biota and safety of the aquatic resources for human consumption. Some environmental variables such as alkalinity, temperature, biochemical oxygen demand (BOD), conductivity, total dissolved solid (TDS), carbon (iv) oxide $\left(\mathrm{CO}_{2}\right)$, total hardness, chemical oxygen demand (COD), turbidity, phosphate, dissolved oxygen (DO), $\mathrm{pH}$, salinity, sulphate and nitrate, and some heavy metals $(\mathrm{Fe}, \mathrm{Cu}, \mathrm{Zn}, \mathrm{Pb}$, $\mathrm{Cd}$ and $\mathrm{Cr}$ ) in water, sediment, aquatic plant (Eichhornia crassipes) and fish (Ethmalosa fimbriata) were measured using standard procedures. The results showed that BOD, COD, total hardness and turbidity values were above the standard permissible limits. $\mathrm{Cd}$ in water column of Agboju and Ajegunle, and $\mathrm{Pb}$ recorded from Agboju, Ajegunle and Topo, exceeded standard permissible limit. $\mathrm{Cu}(0.56 \pm 0.54), \mathrm{Zn}(5.45 \pm 0.89), \mathrm{Pb}(0.54 \pm 0.47)$ and $\mathrm{Cr}(0.455 \pm 0.375)$ contents in E. fimbriata (from Ajegunle) was slightly above permissible limits while $\mathrm{Cd}$ and Fe contents in the fish across the four stations were above permissible limits. Contamination factor, Index of geochemical accumulation and enrichment factor showed moderate degree of contamination of cadmium and $\mathrm{Fe}$ in the sediment. This preliminary study could be concluded that the biota can still survive in the ecosystems despite high contamination of the water bodies with metals. However, human consumption of several of $E$. fimbriata and water could cause health hazard. Therefore, urgent effort should be made by all users of the ecosystem to decline in discharging untreated waste into these water bodies.
\end{abstract}

Keywords: Aquatic Ecosystem, Badagry Division, Nigeria, Biota, Contamination

\section{Introduction}

Productivity and sustainability of water are usually known by the physicochemical properties of water quality. Due to indiscriminate release of wastes, physico-chemical characteristics of water do changes and this could cause hazard effect to flora and fauna of the aquatic ecosystem. Naturally, waters contain some impurities such as metals whose nature and amount vary with source. Some trace metals like copper, zinc, cobalt, iron, and manganese are essential nutrients to plants at very low concentrations. However, high concentrations of these metals are potential toxins to many biological systems. Reports have shown that high level of pollution with heavy metals result from terrigenous activities, atmospheric precipitation, industrial discharge or domestic sewage and non-point source run-off [1]. The hazard of an environmental chemical is a function of its environmental persistence, toxicity, and bio-accumulative potential. Hence, heavy metals are considered hazardous due to its persistence, bioaccumulation, and toxicity features. In many developing 
countries, improper management of domestic waste, burning of fossil fuels, industrial wastes, agricultural run-off and mining of metals have created a potential source of pollution in the aquatic environment of many countries including Nigeria [2].

Some recent research findings have shown that there is continual pollution of Nigerian waters as attested to by high accumulation of toxic metals in fishes caught in them [3-10]. As a result, it becomes imperative to carry out periodic assessment of aquatic ecosystems in Nigeria.

Therefore, this study examined the physicochemical properties and concentrations of some heavy metals in water column, sediment, Eichhornia crassipes and Ethmalosa fimbriata from four aquatic ecosystems (Agboju, Gbaji, Topo and Ajegunle) within Badagry Division of Lagos State, Nigeria with a view to determine the suitability and safety of the biota in the water bodies as well as their safety for consumption.

\section{Materials and Methods}

\subsection{Study Area}

Badagry Division lies between longitude $2^{\circ} 42^{\prime} \mathrm{E}$ and $3^{\circ} 22^{\prime} \mathrm{E}$ and between latitude $6^{\circ} 22^{\prime} \mathrm{N}$ and $6^{\circ} 42^{\prime} \mathrm{N}$. It is bounded in the west by Republic of Benin and in south by the Atlantic Ocean. Also, it is bounded by Alimosho Local Government Area in the north but bounded in the east by Apapa Local Government Area. Badagry Division is surrounded by lagoons, rivers, streams, lakes and creeks.

Badagry Division in Lagos State, Nigeria consists of four local government areas namely Ojo, Amuwo-Odofin, Ajeromi- Ifelodun and Badagry. The study stations namely Gbaji and Topo (In Badagry Creek), Agboju (In Lagos Lagoon) and Ajegunle (In Ajegunle Creek) are as shown in Figure 1. Gbaji and Topo are located in Badagry Local Government Area. Agboju is located in Amuwo Odofin Local Government Area while Ajegunle is located in Ajeromi Ifelodun Local Government Area.

From record of national census in 2016, Amuwo Odofin LGA had a population of over 1,500,000, and shares its boundaries with Ajeromi Ifelodun which had population of $1,746,634$ while Gbaji and Topo had a population of about 250,000 respectively.

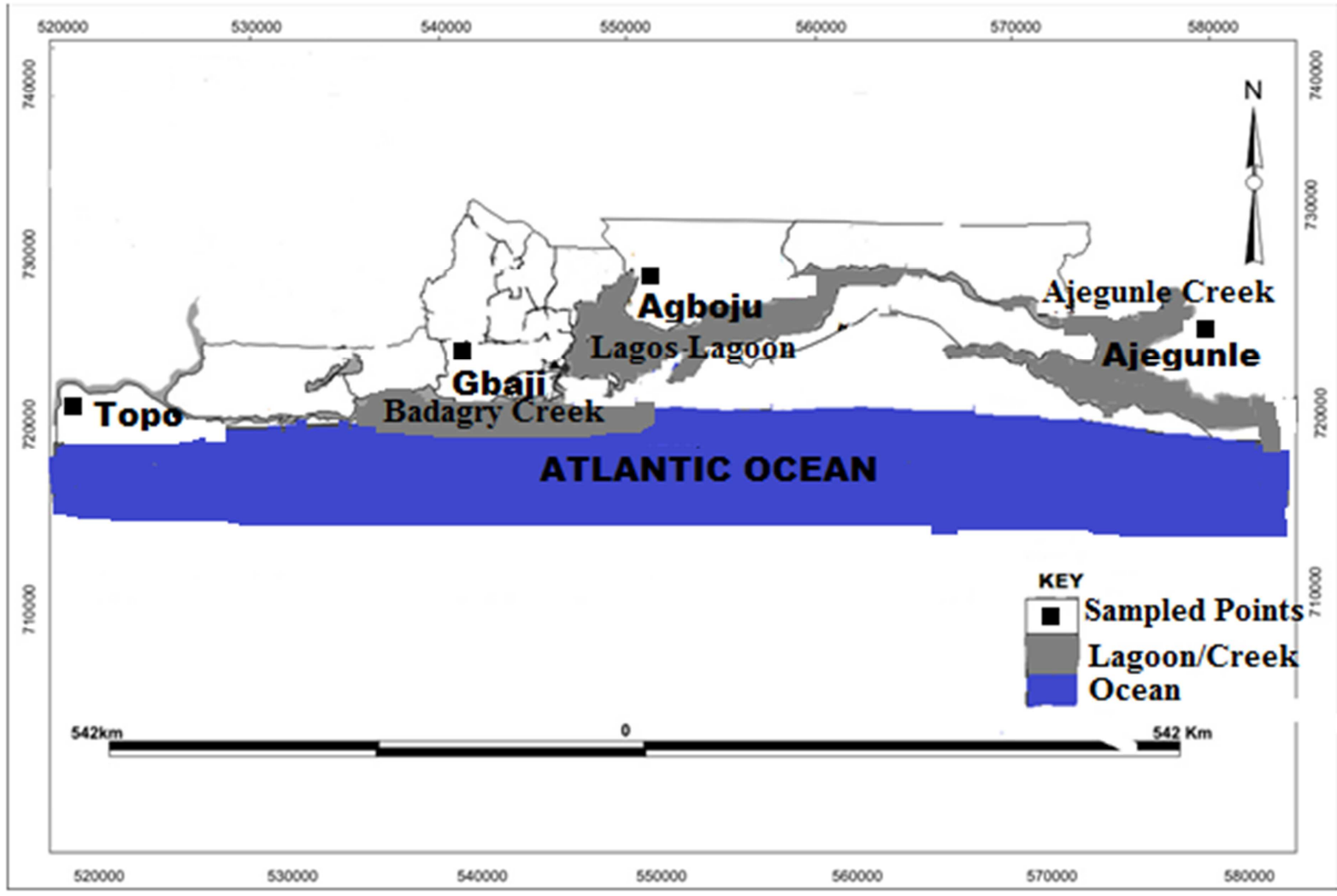

Figure 1. Map Showing the location of Topo and Gbaji (In Badagry Creek), Agboju (In Lagos Lagoon) and Ajegunle (In Ajegunle Creek) across Badagry Division of Lagos State, Nigeria.

\subsection{Collection and Pre-Treatment of Samples}

Samples of water, 96 samples of sediment, 192 samples of Eichhornia crassipes and 192 samples of Ethmalosa fimbriata (Bonga fish) were collected from four sampling stations (Topo, Gbaji, Agboju and Ajegunle) in Badagry Division of Lagos State, Nigeria for six months. The study period comprises of 3 months of wet season (April - June, 2018) and dry season (September-November, 2018). Two (2) sampling points were chosen at each sampling station. Water was collected $20 \mathrm{~cm}$ below the water surface from each sampling point twice every month by using acid-clean 2.5L polycarbonate bottles. From each water sample collected, $100 \mathrm{~mL}$ was measured and acidified with $0.5 \mathrm{~mL}$ of $\mathrm{HNO}_{3}$ to prevent microbial 
degradation of the metals present in the water. Water sample was refrigerated at $-4^{\circ} \mathrm{C}$ before laboratory analysis.

Environmental variables (Physicochemical parameters) measured include alkalinity $(\mathrm{mg} / \mathrm{L})$, temperature $\left({ }^{\circ} \mathrm{C}\right)$, biochemical oxygen demand (BOD, mg/L), electrical conductivity (EC, $\mu \mathrm{s} / \mathrm{cm}$ ), total dissolved solids (TDS, $\mathrm{mg} / \mathrm{L}$ ), Carbon (iv) oxide $\left(\left(\mathrm{CO}_{2}, \mathrm{mg} / \mathrm{L}\right)\right.$, total hardness $(\mathrm{mg} / \mathrm{L})$, chemical oxygen demand (COD, mg/L), turbidity (NTU), phosphate $(\mathrm{mg} / \mathrm{L})$, dissolved oxygen (DO, $\mathrm{mg} / \mathrm{L}), \mathrm{pH}$, salinity $(\mathrm{ppt})$, sulphate $(\mathrm{mg} / \mathrm{L})$ and nitrate $(\mathrm{mg} / \mathrm{L})$. All the parameters were measured according to standard procedures [11-12]. All Samples of fresh Ethmalosa fimbriata, sediment and fresh

Eichhornia crassipes were collected and transported in polyethylene bags, previously cleaned and treated with $5 \%$ $\mathrm{HNO}_{3}$ and rinsed with distilled water [11]. The E. fimbriata and E. crassipes samples were washed with tap water and stored in a freezer at $-4^{\circ} \mathrm{C}$ for 96 hours.

\subsection{Heavy Metal Analysis}

All frozen samples were defrosted at $25^{\circ} \mathrm{C}$ attained in 5 hours. The heavy metals such as iron $(\mathrm{Fe})$, copper $(\mathrm{Cu})$, zinc $(\mathrm{Zn})$, lead $(\mathrm{Pb})$, cadmium $(\mathrm{Cd})$ and chromium $(\mathrm{Cr})$ concentrations in water samples were determined using Buck Scientific Atomic Absorption Spectrophotometer (VGP 210 model, USA). Sediment samples were dried with crucible for $12 \mathrm{~min}$ and thereafter allowed to cool and sieved with $0.5 \mathrm{~mm}$ sieve in preparation for digestion and heavy metal analysis. Metal content of the digested sediment samples was determined using Atomic Absorption Spectrophotometer (Buck scientific 210VGP model). 40 Samples of whole fresh E. fimbriata and E. crassipes were selected from each sampling station, weighed and oven-dried at $105^{\circ} \mathrm{C}$ for 28 hours till a constant weight was obtained. Dried samples were grounded with ceramic mortar and pestle, into powdery form and $3 \mathrm{~g}$ of each sample was digested according to APHA standard [11]. The concentration of the metals was calculated in $\mathrm{mg} / \mathrm{kg}$ while the analytical procedure was checked using reference material (DORM 1, Institute of Environmental Chemistry, NRC Canada).

\subsection{Enrichment Factor (EF)}

Enrichment factor is used to estimate the anthropogenic impact on sediments [13]. The EF calculation reduces the metal variability associated with variations in sediment ratios. The EF method normalizes the measured heavy metal content with respect to a sample reference metal such as iron. In this study, sample reference metal used is iron $(\mathrm{Fe})$ since Fe has a relatively high concentration in the earth while Gbaji is used as control station, as it contains element with low occurrence variability.

$$
\mathrm{EF}=\left(\mathrm{C}_{\mathrm{i}} / \mathrm{C}_{\mathrm{ie}}\right) \mathrm{s} /\left(\mathrm{C}_{\mathrm{i}} / \mathrm{C}_{\mathrm{ie}}\right) \mathrm{rs}
$$

Where $\mathrm{C}_{\mathrm{i}}=$ content of element $\mathrm{i}$ in the sample of interest or the selected reference sample.

$\mathrm{Cie}=$ content of immobile element in the sample or selected reference sample.

(CiCie) $\mathrm{s}=$ heavy metal to immobile element ratio in the samples of interest or examined environment.

(CiCie) $\mathrm{rs}=$ heavy metal to immobile element ratio in the selected reference sample. Based on enrichment factor, 5 contamination categories are recognized namely $\mathrm{EF}<2=$ minimal enrichment, $2 \leq \mathrm{EF}<5=$ moderate enrichment, $5 \leq \mathrm{EF}<20=$ significant enrichment, $20 \leq \mathrm{EF}<40=$ very high enrichment, and $\mathrm{EF}>40=$ extremely high enrichment.

\subsection{Index of Geo-accumulation $\left(I_{g e o}\right)$}

Index of geo - accumulation is used in determining metal contamination in sediments, by comparing current concentration with pre- industrial levels [14].

$$
\mathrm{I}_{\text {geo }}=\log 2\left(\mathrm{C}_{\mathrm{i}} / 1.5 \mathrm{C}_{\mathrm{ri}}\right)
$$

Where $\mathrm{C}_{\mathrm{i}}=$ measured concentration of the examined metal $\mathrm{i}$ in the sediment.

$\mathrm{C}_{\mathrm{ri}}=$ reference value of the metal $\mathrm{i}$ or geochemical background concentration of the metal i. Factor 1.5 helps to minimize possible variations in background values for a given metal. Background value for this study was considered from world average value in shale $(\mathrm{mg} / \mathrm{kg})$.

Geo-accumulation index has 7 categories namely:

Class $0=\mathrm{I}_{\text {geo }} \leq 0$ (practically uncontaminated), Class $1=0<\mathrm{I}_{\mathrm{geo}}<1$ (uncontaminated to moderately contaminated), Class $2=1<\mathrm{I}_{\text {geo }}<2$ (moderately contaminated), Class $3=2<\mathrm{I}_{\text {geo }}<3$ (moderately to heavily contaminated), Class $4=3<\mathrm{I}_{\text {geo }}<4$ (heavily contaminated), Class $5=4<\mathrm{I}_{\text {geo }}<5$ (heavily to extremely contaminated), Class $6=5<\mathrm{I}_{\mathrm{geo}}>6$ (extremely contaminated).

\subsection{Contamination Factor}

The Contamination Factor (CF) describes the level of contamination of a given metal in sediment over a period of time. $\mathrm{CF}$ is expressed as: $\mathrm{Cm} / \mathrm{Cb}$, where $\mathrm{Cm}=$ Concentration of a particular metal in sediment, and $\mathrm{Cb}$ is the background metal. The background for this study was taken from DPR [15].

$\mathrm{CF}<1=$ low degree of contamination, $1 \leq \mathrm{CF}<3=$ moderate degree of contamination, $3 \leq \mathrm{CF}<6=$ considerable degree of contamination, and $\mathrm{CF} \geq 6=$ very high degree of contamination.

\subsection{Statistical Analyses}

All Data for spatial and seasonal variations of the metals in the samples were tested by one-way Analysis of Variance (ANOVA) and results expressed as mean \pm standard deviation while Duncan Multiple Range Post-hoc test was used to separate the means. The level of significance was set at $p<0.05$.

Also, Enrichment Factor, Contamination Factor (CF) and Index of geo - accumulation were analyzed using standard equations and formulars.

\section{Results}

\subsection{Environmental Variables of Water Samples}

The spatial variation of the environmental variables 
(Physicochemical parameters) at each sampling site was presented in Table 1. There were no significant spatial variation $(p>0.05)$ in the values recorded for temperature, carbon (iv) oxide $\left(\mathrm{CO}_{2}\right)$, phosphate, dissolved oxygen (DO), $\mathrm{pH}$, salinity and sulphate across the four sampling stations. Gbaji had the highest value of alkalinity $(38.44 \pm 6.96 \mathrm{mg} / \mathrm{L})$ and total dissolved solid (TDS, $135.89 \pm 28.74 \mathrm{mg} / \mathrm{L}$ ) but lowest values in conductivity $(220.27 \pm 30.97 \mu \mathrm{s} / \mathrm{cm})$, total hardness $(191.45 \pm 10.89 \mathrm{mg} / \mathrm{L})$, Chemical oxygen demand (COD, $166.21 \pm 20.93 \mathrm{mg} / \mathrm{L})$ and turbidity $(39.35 \pm 6.26 \mathrm{NTU})$. The highest Biochemical Oxygen Demand (BOD, $217.50 \pm 28.37 \mathrm{mg} / \mathrm{L})$, electrical conductivity $(265.30 \pm 45.41$ $\mu \mathrm{s} / \mathrm{cm})$, total hardness $(238.25 \pm 18.91 \mathrm{mg} / \mathrm{L})$, chemical oxygen demand (COD, $180.46 \pm 25.29)$, turbidity $(48.63 \pm 7.08$ NTU) and nitrate $(5.98 \pm 0.84 \mathrm{mg} / \mathrm{L})$ were recorded in Ajegunle. However, Ajegunle had the lowest alkalinity $(31.75 \pm 4.21 \mathrm{mg} / \mathrm{L})$. On the contrary, the lowest TDS $(116.61 \pm 5.78 \mathrm{mg} / \mathrm{L})$ and lowest nitrate $(4.30 \pm 0.74 \mathrm{mg} / \mathrm{L})$ were obtained from Agboju, while the least value in BOD $(205.46 \pm 24.19 \mathrm{mg} / \mathrm{L})$ was recorded in Topo.
There were significant $(\mathrm{p}<0.05)$ spatial variations between alkalinity values in Gbaji, Agboju and Topo in comparison with that of Ajegunle as shown in Table 1. Also, the spatial variations in the electrical conductivity, TDS and total hardness respectively among Agboju $(254.37 \pm 42.12 \mu \mathrm{s} / \mathrm{cm}$, $116.61 \pm 5.78 \mathrm{mg} / \mathrm{L}$ and $208.85 \pm 14.76 \mathrm{mg} / \mathrm{L}), \quad$ Gbaji $(220.27 \pm 30.97 \mu \mathrm{s} / \mathrm{cm}, \quad 135.89 \pm 28.74 \mathrm{mg} / \mathrm{L} \quad$ and $191.45 \pm 10.89 \mathrm{mg} / \mathrm{L}), \quad$ Ajegunle $\quad(265.30 \pm 45.41 \mu \mathrm{s} / \mathrm{cm}$, $124.97 \pm 4.38 \mathrm{mg} / \mathrm{L}$ and $238.25 \pm 18.91 \mathrm{mg} / \mathrm{L})$ and Topo $(236.60 \pm 40.48 \mu \mathrm{s} / \mathrm{cm}, \quad 130.98 \pm 24.12 \mathrm{mg} / \mathrm{L} \quad$ and $197.37 \pm 5.53 \mathrm{mg} / \mathrm{L}$ ) were significant (Table 1). While only nitrate values recorded in Ajegunle was significantly $(\mathrm{p}<0.05)$ high, the spatial variations of biochemical oxygen demand (BOD) in the sampling sites (except between Topo $(205.46 \pm 24.19 \mathrm{mg} / \mathrm{L})$ and Gbaji $(205.88 \pm 23.48))$ was significant $(\mathrm{p}<0.05)$. Similarly, there were no significant $(\mathrm{p}>0.05)$ spatial variations in COD and Turbidity values between Gbaji $(166.21 \pm 20.93 \mathrm{mg} / \mathrm{L}, 39.35 \pm 6.26 \mathrm{NTU})$ and Topo (166.21 $\pm 20.93 \mathrm{mg} / \mathrm{L}, 40.68 \pm 5.05 \mathrm{NTU})$.

Table 1. Spatial Variation of Water Physico-chemical Parameters of Four Aquatic Ecosystems in Badagry Division, Lagos, Nigeria.

\begin{tabular}{|c|c|c|c|c|}
\hline Parameters & Agboju & Gbaji & Ajegunle & Topo \\
\hline Alkalinity (mg/L) & $37.37 \pm 5.63^{\mathrm{a}}$ & $38.44 \pm 6.96^{\mathrm{a}}$ & $31.75 \pm 4.21^{\mathrm{b}}$ & $38.09 \pm 6.49^{\mathrm{a}}$ \\
\hline Temperature $\left({ }^{\circ} \mathrm{C}\right)$ & $28.03 \pm 2.32^{\mathrm{a}}$ & $27.49 \pm 1.99^{\mathrm{a}}$ & $28.63 \pm 2.45^{\mathrm{a}}$ & $27.82 \pm 2.11^{\mathrm{a}}$ \\
\hline $\mathrm{BOD}(\mathrm{mg} / \mathrm{L})$ & $212.31 \pm 26.46^{\mathrm{a}}$ & $205.88 \pm 23.48^{\mathrm{b}}$ & $217.50 \pm 28.37^{\mathrm{ab}}$ & $205.46 \pm 24.19^{b}$ \\
\hline TDS (mg/L) & $116.61 \pm 5.78^{\mathrm{a}}$ & $135.89 \pm 28.74^{\mathrm{b}}$ & $124.97 \pm 4.38^{\mathrm{ab}}$ & $130.98 \pm 24.12^{\mathrm{ac}}$ \\
\hline $\mathrm{CO} 2(\mathrm{mg} / \mathrm{L})$ & $8.73 \pm 1.65^{\mathrm{a}}$ & $8.38 \pm 2.11^{\mathrm{a}}$ & $9.77 \pm 2.09^{\mathrm{a}}$ & $8.40 \pm 2.17^{\mathrm{a}}$ \\
\hline Total Hardness $(\mathrm{mg} / \mathrm{L})$ & $208.85 \pm 14.76^{\mathrm{a}}$ & $191.45 \pm 10.89^{\mathrm{b}}$ & $238.25 \pm 18.91^{\mathrm{ab}}$ & $197.37 \pm 5.53^{\mathrm{ac}}$ \\
\hline Turbidity (NTU) & $45.43 \pm 6.76^{\mathrm{a}}$ & $39.35 \pm 6.26^{\mathrm{b}}$ & $48.63 \pm 7.08^{\mathrm{ab}}$ & $40.68 \pm 5.05^{\mathrm{b}}$ \\
\hline Phosphate (mg/L) & $4.56 \pm 0.84^{\mathrm{a}}$ & $4.34 \pm 0.66^{\mathrm{a}}$ & $5.17 \pm 1.03^{\mathrm{a}}$ & $4.41 \pm 0.78^{\mathrm{a}}$ \\
\hline $\mathrm{DO}(\mathrm{mg} / \mathrm{L})$ & $6.20 \pm 0.61^{\mathrm{a}}$ & $6.33 \pm 0.88^{\mathrm{a}}$ & $5.77 \pm 0.78^{\mathrm{a}}$ & $6.76 \pm 0.99^{\mathrm{a}}$ \\
\hline $\mathrm{pH}(\mathrm{mg} / \mathrm{L})$ & $7.18 \pm 0.54^{\mathrm{a}}$ & $7.32 \pm 0.44^{\mathrm{a}}$ & $7.06 \pm 0.53^{\mathrm{a}}$ & $7.43 \pm 0.52^{\mathrm{a}}$ \\
\hline Salinity (ppt) & $0.037 \pm 0.032^{\mathrm{a}}$ & $0.081 \pm 0.099^{\mathrm{a}}$ & $0.040 \pm 0.040^{\mathrm{a}}$ & $0.068 \pm 0.067^{\mathrm{a}}$ \\
\hline Sulphate $(\mathrm{mg} / \mathrm{L})$ & $4.29 \pm 0.88^{\mathrm{a}}$ & $4.26 \pm 0.43^{\mathrm{a}}$ & $4.43 \pm 0.59^{\mathrm{a}}$ & $4.11 \pm 0.41^{\mathrm{a}}$ \\
\hline Nitrate $(\mathrm{mg} / \mathrm{L})$ & $4.30 \pm 0.74^{\mathrm{a}}$ & $4.98 \pm 0.82^{\mathrm{a}}$ & $5.98 \pm 0.84^{\mathrm{ab}}$ & $4.54 \pm 0.89^{\mathrm{a}}$ \\
\hline
\end{tabular}

Mean \pm SD values with different superscript in the row are significantly $(\mathrm{p}<0.05)$ different.

The respective wet and dry seasonal variations for alkalinity $(38.59 \pm 5.94 \mathrm{mg} / \mathrm{L}, \quad 34.23 \pm 5.81 \mathrm{mg} / \mathrm{L}), \quad$ temperature $\left(26.41 \pm 0.93^{\circ} \mathrm{C}, \quad 29.57 \pm 1.75^{\circ} \mathrm{C}\right), \quad$ BOD $\quad(187.73 \pm 3.84 \mathrm{mg} / \mathrm{L}$, $232.84 \pm 11.42 \mathrm{mg} / \mathrm{L}), \quad$ conductivity $\quad(277.74 \pm 30.76 \mu \mathrm{s} / \mathrm{cm}$, $210.50 \pm 12.44 \mu \mathrm{s} / \mathrm{cm}) \quad$ TDS $\quad(139.14 \pm 19.43 \mathrm{mg} / \mathrm{L}$, $115.09 \pm 9.13 \mathrm{mg} / \mathrm{L}), \mathrm{CO}_{2}(7.11 \pm 0.73 \mathrm{mg} / \mathrm{L}, 10.52 \pm 1.09 \mathrm{mg} / \mathrm{L})$, totalhardness $(205.38 \pm 27.52 \mathrm{mg} / \mathrm{L}, 212.56 \pm 15.88 \mathrm{mg} / \mathrm{L}), \mathrm{COD}$ $(156.03 \pm 6.19 \mathrm{mg} / \mathrm{L}, \quad 189.00 \pm 18.36 \mathrm{mg} / \mathrm{L}), \quad$ turbidity (39.19 $\pm 5.80 \mathrm{NTU}, \quad 47.86 \pm 5.34 \mathrm{NTU}), \quad$ phosphate $(4.77 \pm 1.02 \mathrm{mg} / \mathrm{L}, \quad 4.47 \pm 0.65 \mathrm{mg} / \mathrm{L}), \quad$ DO $\quad(6.78 \pm 0.72 \mathrm{mg} / \mathrm{L}$, $5.75 \pm 0.64 \mathrm{mg} / \mathrm{L}), \quad \mathrm{pH} \quad(7.56 \pm 0.44, \quad 6.93 \pm 0.32), \quad$ salinity $(0.093 \pm 0.074 \mathrm{ppt}, 0.021 \pm 0.012 \mathrm{ppt})$, sulphate $(4.68 \pm 0.45 \mathrm{mg} / \mathrm{L}$, $3.87 \pm 0.38 \mathrm{mg} / \mathrm{L})$ andnitrate $(5.34 \pm 1.04 \mathrm{mg} / \mathrm{L}, 4.56 \pm 0.84 \mathrm{mg} / \mathrm{L})$ are as shown in Figure 2. The parameters (except $\mathrm{CO}_{2}$, phosphate, DO, $\mathrm{pH}$, salinity, sulphate and nitrate) showed significant $(p<0.05)$ seasonal variation across the sampling stations. While alkalinity, conductivity and TDS were higher in wet seasons, temperature, BOD, total hardness, COD and turbidity were significantly high during dry seasons.

\subsection{Heavy Metals Concentration in Water Sample and Eichhornia Crassipes}

There were no significant $(\mathrm{p}>0.05)$ spatial and seasonal variation in heavy metals concentration in water column recorded in this study. The metals recorded in wet season and dry season respectively in the water samples are $\mathrm{Fe}$ $(0.96 \pm 0.28 \mathrm{mg} / \mathrm{L}, \quad 1.47 \pm 0.45 \mathrm{mg} / \mathrm{L}), \quad \mathrm{Cu} \quad(0.23 \pm 0.14 \mathrm{mg} / \mathrm{L}$, $0.59 \pm 0.28 \mathrm{mg} / \mathrm{L}), \mathrm{Zn}(0.70 \pm 0.48 \mathrm{mg} / \mathrm{L}, 0.89 \pm 0.37 \mathrm{mg} / \mathrm{L}), \mathrm{Pb}$ $(0.045 \pm 0.033 \mathrm{mg} / \mathrm{L}, \quad 0.118 \pm 0.111 \mathrm{mg} / \mathrm{L}), \quad \mathrm{Cd}$ $(0.003 \pm 0.003 \mathrm{mg} / \mathrm{L}, \quad 0.007 \pm 0.003 \mathrm{mg} / \mathrm{L}) \quad$ and $\quad \mathrm{Cr}$ $(0.005 \pm 0.003 \mathrm{mg} / \mathrm{L}, 0.007 \pm 0.007 \mathrm{mg} / \mathrm{L})$. The spatial heavy metals in water sample of Agboju, Gbaji, Ajegunle and Topo respectively are: $\mathrm{Fe}(1.13 \pm 0.59 \mathrm{mg} / \mathrm{L}, \quad 1.09 \pm 0.28 \mathrm{mg} / \mathrm{L}$, $1.56 \pm 0.45 \mathrm{mg} / \mathrm{L}, \quad 1.10 \pm 0.25 \mathrm{mg} / \mathrm{L}), \quad \mathrm{Cu} \quad(0.29 \pm 0.27 \mathrm{mg} / \mathrm{L}$, $0.28 \pm 0.17 \mathrm{mg} / \mathrm{L}, \quad 0.60 \pm 0.47 \mathrm{mg} / \mathrm{L}, \quad 0.30 \pm 0.28 \mathrm{mg} / \mathrm{L}), \quad \mathrm{Zn}$ $(0.81 \pm 0.29 \mathrm{mg} / \mathrm{L}, \quad 0.62 \pm 0.34 \mathrm{mg} / \mathrm{L}, \quad 1.29 \pm 0.39 \mathrm{mg} / \mathrm{L}$, $0.49 \pm 0.27 \mathrm{mg} / \mathrm{L}), \mathrm{Pb}(0.074 \pm 0.070 \mathrm{mg} / \mathrm{L}, 0.027 \pm 0.019 \mathrm{mg} / \mathrm{L}$, $0.154 \pm 0.164 \mathrm{mg} / \mathrm{L}, 0.058 \pm 0.043 \mathrm{mg} / \mathrm{L}), \mathrm{Cd}(0.004 \pm 0.003 \mathrm{mg} / \mathrm{L}$, 
$0.003 \pm 0.002 \mathrm{mg} / \mathrm{L}, 0.009 \pm 0.006 \mathrm{mg} / \mathrm{L}, 0.003 \pm 0.001 \mathrm{mg} / \mathrm{L})$ and Cr $(0.004 \pm 0.002 \mathrm{mg} / \mathrm{L}, 0.004 \pm 0.003 \mathrm{mg} / \mathrm{L}, 0.011 \pm 0.009 \mathrm{mg} / \mathrm{L}$, $0.005 \pm 0.003 \mathrm{mg} / \mathrm{L})$.

Only $\mathrm{Fe}$ and $\mathrm{Zn}$ content in the E. crassipes had spatial significant difference $(\mathrm{p}<0.05)$ across the sampling stations. The highest values of Fe $(270.89 \pm 41.25 \mathrm{mg} / \mathrm{kg})$ and $\mathrm{Zn}$ $(11.09 \pm 3.67 \mathrm{mg} / \mathrm{kg})$ were recorded in Ajegunle while the lowest Fe $(108.19 \pm 9.82 \mathrm{mg} / \mathrm{kg})$ and $\mathrm{Zn}(8.92 \pm 5.99 \mathrm{mg} / \mathrm{kg})$ was obtained from Gbaji. However, there were no significant ( $p>0.05$ ) differences between the Fe and $\mathrm{Zn}$ contents recorded in Gbaji and Topo. While the values of $\mathrm{Pb}(1.12 \pm 0.60 \mathrm{mg} / \mathrm{kg}$, $1.39 \pm 0.55 \mathrm{mg} / \mathrm{kg}), \mathrm{Cd}(0.59 \pm 0.28,0.90 \pm 0.49) \mathrm{Cr}(0.34 \pm 0.33$, $0.90 \pm 0.52)$ and $\mathrm{Cu}(1.49 \pm 0.57,1.27 \pm 0.32)$ during wet and dry season respectively, had no significant $(\mathrm{p}>0.05)$ variation, other metals $(\mathrm{Fe}$ and $\mathrm{Zn})$ recorded in E. crassipes showed significant $(\mathrm{p}<0.05)$ seasonal variation across the sampling sites. The peak value of Fe $(178.72 \pm 84.05 \mathrm{mg} / \mathrm{kg})$ and $\mathrm{Zn}$ $(14.37 \pm 3.54 \mathrm{mg} / \mathrm{kg})$ in E. crassipes were obtained during dry season while the lower values of Fe $(167.78 \pm 61.48 \mathrm{mg} / \mathrm{kg})$ and $\mathrm{Zn}(5.86 \pm 1.85 \mathrm{mg} / \mathrm{kg})$ in E. crassipes were recorded in wet season.

\subsection{Heavy Metal Content in Sediment}

Only $\mathrm{Fe}, \mathrm{Cu}$ and $\mathrm{Zn}$ showed significant $(\mathrm{p}<0.05)$ spatial variation of heavy metals content in the sediment examined from the four sampling stations (Table 2). The peak Fe $(1405.51 \pm 126.23 \mathrm{mg} / \mathrm{kg}), \quad \mathrm{Cu}(11.96 \pm 2.62 \mathrm{mg} / \mathrm{kg})$ and $\mathrm{Zn}$ $(19.15 \pm 4.66 \mathrm{mg} / \mathrm{kg})$ contents in the sediment was obtained from Ajegunle. On the other hand, the lowest $\mathrm{Fe}$ $(1056.50 \pm 100.09 \mathrm{mg} / \mathrm{kg})$ was recorded in Gbaji, while lowest $\mathrm{Cu} \quad(7.74 \pm 1.73 \mathrm{mg} / \mathrm{kg})$ and $\mathrm{Zn}(12.84 \pm 1.77 \mathrm{mg} / \mathrm{kg})$ were obtained from Topo. Similarly, significant $(p<0.05)$ seasonal variation were recorded only for $\mathrm{Fe}, \mathrm{Cu}$ and $\mathrm{Zn}$ in this study. The lowest seasonal values of Fe $(1143.75 \pm 169.26 \mathrm{mg} / \mathrm{kg}), \mathrm{Cu}$ $(8.66 \pm 2.21 \mathrm{mg} / \mathrm{kg})$, and $\mathrm{Zn}(13.73 \pm 2.33 \mathrm{mg} / \mathrm{kg})$ in the sediment were recorded in wet season, while the higher seasonal values of $\mathrm{Fe}(1260.35 \pm 189.07 \mathrm{mg} / \mathrm{kg}), \mathrm{Cu}$ $(10.67 \pm 3.15 \mathrm{mg} / \mathrm{kg})$ and $\mathrm{Zn}(17.89 \pm 4.84 \mathrm{mg} / \mathrm{kg})$ were obtained in dry season. The values of other metals in sediment during wet and dry season respectively are $\mathrm{Pb}(1.47 \pm 0.70 \mathrm{mg} / \mathrm{kg}$, $1.59 \pm 0.94 \mathrm{mg} / \mathrm{kg}), \quad \mathrm{Cd}(1.16 \pm 0.36 \mathrm{mg} / \mathrm{kg}, \quad 1.13 \pm 0.58 \mathrm{mg} / \mathrm{kg})$ and $\mathrm{Cr}(1.14 \pm 0.34 \mathrm{mg} / \mathrm{kg}, 1.25 \pm 0.47 \mathrm{mg} / \mathrm{kg})$.

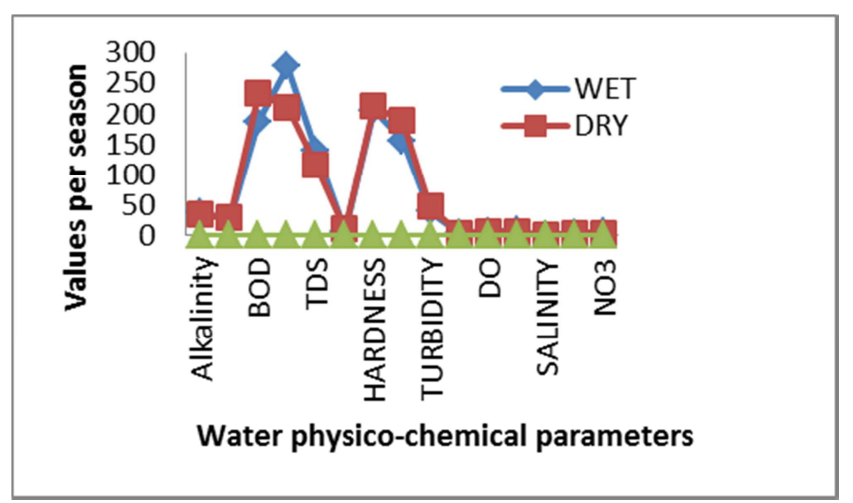

Figure 2. Seasonal Variation of Water Physico-chemical Parameters.

Table 2. Spatial Variation of Heavy Metals Concentration in Sediment from Four Aquatic Ecosystems in Badagry Division, Lagos, Nigeria.

\begin{tabular}{llll}
\hline Heavy Metals & Agboju & Gbaji & Ajegunle \\
\hline $\mathrm{Fe}(\mathrm{mg} / \mathrm{kg})$ & $1347.39 \pm 116.38^{\mathrm{a}}$ & $1056.50 \pm 100.09^{\mathrm{b}}$ & $1405.51 \pm 126.23^{\mathrm{ab}}$ \\
$\mathrm{Cu}(\mathrm{mg} / \mathrm{kg})$ & $10.83 \pm 3.23^{\mathrm{ab}}$ & $8.13 \pm 1.14^{\mathrm{b}}$ & $11.96 \pm 2.62^{\mathrm{ab}}$ \\
$\mathrm{Zn}(\mathrm{mg} / \mathrm{kg})$ & $17.72 \pm 4.33^{\mathrm{a}}$ & $13.54 \pm 2.06^{\mathrm{b}}$ & $1063.07 \pm 94.62^{\mathrm{ac}}$ \\
$\mathrm{Pb}(\mathrm{mg} / \mathrm{kg})$ & $1.50 \pm 0.44^{\mathrm{a}}$ & $1.22 \pm 0.31^{\mathrm{a}}$ & $7.74 \pm 1.73^{\mathrm{b}}$ \\
$\mathrm{Cd}(\mathrm{mg} / \mathrm{kg})$ & $1.22 \pm 0.19^{\mathrm{a}}$ & $0.83 \pm 0.22^{\mathrm{a}}$ & $2.34 \pm 1.25^{\mathrm{a}}$ \\
$\mathrm{Cr}(\mathrm{mg} / \mathrm{kg})$ & $1.33 \pm 0.35^{\mathrm{a}}$ & $0.92 \pm 0.18^{\mathrm{a}}$ & $1.68 \pm 0.58^{\mathrm{a}}$ \\
\hline
\end{tabular}

Mean \pm SD values with same superscript in the row are not significantly $(p>0.05)$ different.

\subsection{Enrichment Factor, Index of Geochemical}

Accumulation and Contamination Factor of Sediment Sample

The values of enrichment factor (EF), index of geochemical accumulation (Igeo) and contamination factor (CF) of the sediment are presented in Figure 3, Tables 3 and 4 respectively. The computed EF values of heavy metals for Agboju are: $\mathrm{Fe}$ (1.000), Cu (1.045), Zn (1.026), Pb (0.964), Cd (1.153) and $\mathrm{Cr}$ (1.134). Similarly, Ajegunle sediment had EF values of $\mathrm{Fe}$ (1.000), $\mathrm{Cu}$ (1.106), $\mathrm{Zn}$ (1.063), $\mathrm{Pb}$ (1.442), Cd (1.521) and $\mathrm{Cr}$ (1.348) while EF obtained from Topo are $\mathrm{Fe}$ (1.000), $\mathrm{Cu}$ (0.945), $\mathrm{Zn}$ (0.942), $\mathrm{Pb}$ (0.872), $\mathrm{Cd}$ (1.018) and $\mathrm{Cr}$ (0.983). Only $\mathrm{I}_{\text {geo }}$ of $\mathrm{Cd}(1.12373)$ at Ajegunle was under class 1 while other Igeo of other metals from the four stations fall within Class 0 . The values of $\mathrm{CF}$ in $\mathrm{Cd}$ obtained in sediment from the four sampling stations are: Agboju (1.525), Gbaji (1.038), Ajegunle (2.100) and Topo (1.062). However, the CF values of other metals ( $\mathrm{Fe}, \mathrm{Zn}, \mathrm{Cu}, \mathrm{Pb}$ and $\mathrm{Cr}$ ) across the stations were $<1$ (Table 4).

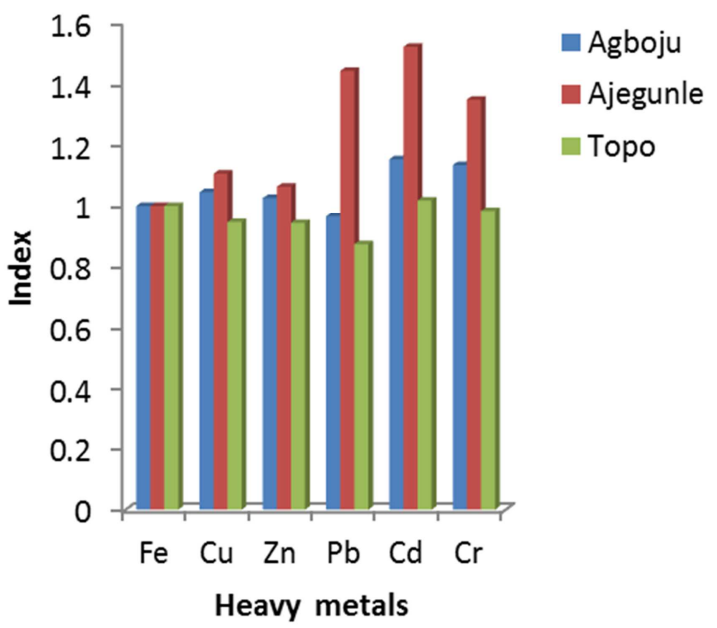

Figure 3. Enrichment Factor (EF) at Agboju, Ajegunle and Topo in Badagry Division, Lagos, Nigeria. 
Table 3. Geo-Accumulation Index in Sediment from Four Aquatic Ecosystems in Badagry Division, Lagos, Nigeria.

\begin{tabular}{llllll}
\hline Heavy Metals & Agboju (Igeo & Gbaji $\left(\mathbf{I}_{\text {geo }}\right)$ & Ajegunle $\left(\mathbf{I}_{\text {geo }}\right)$ & Topo $\left(\mathbf{I}_{\text {geo }}\right)$ & World average value of metals $(\mathbf{m g} / \mathbf{k g})$ \\
\hline $\mathrm{Fe}$ & 0.00579 & 0.00454 & 0.00604 & 0.00457 & 46,700 \\
$\mathrm{Cu}$ & 0.19757 & 0.14831 & 0.21818 & 0.14119 & 45 \\
$\mathrm{Zn}$ & 0.03743 & 0.02860 & 0.04045 & 0.02712 & 95 \\
$\mathrm{~Pb}$ & 0.01505 & 0.01224 & 0.02348 & 0.01074 & 20 \\
$\mathrm{Cd}$ & 0.81604 & 0.55518 & 1.12373 & 0.56856 & 0.3 \\
$\mathrm{Cr}$ & 0.00297 & 0.00205 & 0.00368 & 0.00203 & 90 \\
\hline
\end{tabular}

Table 4. Contamination Factor (CF) in Sediment from Four Aquatic Ecosystems in Badagry Division, Lagos, Nigeria.

\begin{tabular}{llllll}
\hline Metals & Background value & $\mathbf{C}_{\mathbf{f}}$ (Agboju) & $\mathbf{C}_{\mathbf{f}}$ (Gbaji) & $\mathbf{C}_{\mathbf{f}}$ (Ajegunle) & $\mathbf{C}_{\mathbf{f}}$ (Topo) \\
\hline $\mathrm{Fe}$ & 38000 & 0.035 & 0.028 & 0.037 & 0.028 \\
$\mathrm{Cu}$ & 36 & 0.301 & 0.226 & 0.332 & 0.215 \\
$\mathrm{Zn}$ & 140 & 0.127 & 0.097 & 0.137 & 0.092 \\
$\mathrm{~Pb}$ & 85 & 0.018 & 0.014 & 0.028 & 0.013 \\
$\mathrm{Cd}$ & 0.8 & 1.525 & 1.038 & 2.100 & 1.062 \\
$\mathrm{Cr}$ & 100 & 0.013 & 0.009 & 0.017 & 0.009 \\
\hline
\end{tabular}

\subsection{Concentration of Heavy Metals in Ethmalosa Fimbriata}

Only $\mathrm{Zn}$ and $\mathrm{Fe}$ showed spatial variation of heavy metal content in Ethmalosa fimbriata examined in this study. The value of $\mathrm{Zn}(5.45 \pm 0.89 \mathrm{mg} / \mathrm{kg})$ recorded from Ajegunle was significantly $(\mathrm{p}<0.05)$ higher than that from Agboju $(3.88 \pm 0.91 \mathrm{mg} / \mathrm{kg}), \quad$ Gbaji $(3.87 \pm 0.75 \mathrm{mg} / \mathrm{kg}) \quad$ and Topo $(3.86 \pm 0.92 \mathrm{mg} / \mathrm{kg})$. Similarly, the value of $\mathrm{Fe}$ $(11.63 \pm 3.20 \mathrm{mg} / \mathrm{kg})$ obtained in E. fimbriata from Ajegunle and Agboju $(10.86 \pm 2.90 \mathrm{mg} / \mathrm{kg})$ were higher than that from Gbaji $(7.46 \pm 3.01 \mathrm{mg} / \mathrm{kg})$ and Topo $(7.39 \pm 3.70 \mathrm{mg} / \mathrm{kg})$. Other metals (in $\mathrm{mg} / \mathrm{kg}$ ) detected in E. fimbriata from Agboju, Gbaji, Ajegunle and Topo respectively are $\mathrm{Cu}(0.44 \pm 0.34,0.32 \pm 0.19$, $0.56 \pm 0.54,0.06 \pm 0.04), \mathrm{Pb}(0.58 \pm 0.25,0.20 \pm 0.11,0.54 \pm 0.47$, $0.03 \pm 0.02), \quad C d(0.050 \pm 0.044,0.031 \pm 0.029,0.122 \pm 0.116$, $0.081 \pm 0.054)$ and $\mathrm{Cr} \quad(0.070 \pm 0.057, \quad 0.026 \pm 0.023$, $0.455 \pm 0.375,0.087 \pm 0.064)$. The value of heavy metals recorded in E. fimbriata in dry and wet seasons respectively are $\quad \mathrm{Fe} \quad(11.70 \pm 2.64 \mathrm{mg} / \mathrm{kg}, \quad 6.97 \pm 2.99 \mathrm{mg} / \mathrm{kg}), \quad \mathrm{Cu}$ $(0.52 \pm 0.42 \mathrm{mg} / \mathrm{kg}, \quad 0.22 \pm 0.16 \mathrm{mg} / \mathrm{kg}), \mathrm{Zn} \quad(4.72 \pm 1.03 \mathrm{mg} / \mathrm{kg}$, $3.81 \pm 0.96 \mathrm{mg} / \mathrm{kg}), \quad \mathrm{Pb}(0.53 \pm 0.49 \mathrm{mg} / \mathrm{kg}, \quad 0.18 \pm 0.10 \mathrm{mg} / \mathrm{kg})$, $\mathrm{Cd} \quad(0.105 \pm 0.089 \mathrm{mg} / \mathrm{kg}, \quad 0.037 \pm 0.036 \mathrm{mg} / \mathrm{kg})$ and $\mathrm{Cr}$ $(0.326 \pm 0.235 \mathrm{mg} / \mathrm{kg}, 0.132 \pm 0.066 \mathrm{mg} / \mathrm{kg})$. However, only $\mathrm{Fe}$ showed significant $(\mathrm{p}<0.05)$ seasonal variation with the higher value $(11.70 \pm 2.64 \mathrm{mg} / \mathrm{kg})$ in the fish obtained during dry season.

\section{Discussion}

\subsection{Environmental Variables and Heavy Metals in Water Samples}

Only eight parameters (alkalinity, electrical conductivity, TDS, total hardness, BOD, COD, turbidity and nitrate) showed significant spatial variation across the four sampling stations. These findings could suggest that the four aquatic ecosystems exhibit similar physico-chemical properties. The suitability of parameters such as $\mathrm{DO}, \mathrm{pH}$, temperature, $\mathrm{CO}_{2}$, and conductivity in this study could be the basis for the successful fisheries in these water bodies. All the physicochemical parameters (except BOD, COD, total hardness and turbidity) are below the recommended maximum permissible limits [16-18]. All the values recorded for BOD, total hardness, COD and turbidity exceeded $6 \mathrm{mg} / \mathrm{L}$, $100 \mathrm{mg} / \mathrm{L}, 10-40 \mathrm{mg} / \mathrm{L}$ and $5 \mathrm{NTU}$ respectively of permissible limit in water. High BOD, COD, turbidity and hardness is an indication that the water from the four stations has poor quality. The parameters (except alkalinity, hardness, BOD, conductivity and COD) in this study were higher than that reported in Badagry creek [19]. It was also higher than that reported in Cross River Estuary, in Ogbe creek, in Tomaro creek, Tidal creek and from Asejire Lake respectively [10, 20-23]. On the other hand, the values of phosphate, hardness, salinity and TDS in this study were lower than that recorded in Majidun River in Lagos, Nigeria [24]. Similarly, values of all physico-chemical parameters in this study were lower than that reported in Ologe Lagoon, Ojo creek, and Lena River respectively [25-27]. Apart from $\mathrm{CO}_{2}$, phosphate, $\mathrm{DO}, \mathrm{pH}$, salinity, sulphate and nitrate, other parameters showed significant seasonal variation across the sampling stations. Similar seasonal variation has been reported in Ologe Lagoon $[25,28]$. However, no seasonal variation was reported in DO, $\mathrm{pH}$ and salinity in water from Nun and Brass River in Bayelsa State, Nigeria [29].

In this study, alkalinity, conductivity and TDS were higher in wet seasons, while temperature, BOD, total hardness, COD and turbidity were significantly high during dry seasons. In contrast to our findings, high $\mathrm{pH}$, salinity, free carbon (iv) oxide, sulphate and total hardness has been recorded in wet season from Badagry creek [30].

The spatial and seasonal values of heavy metals concentration of water recorded in this study were not significant. This could imply that the water bodies have similar levels of metal contamination. Only values of $\mathrm{Cu}, \mathrm{Fe}$, $\mathrm{Cr}$ and $\mathrm{Zn}$ were below standard maximum permissible limit. This finding differs from other studies that reported higher concentration of the metals in surface water during the dry season [31-32]. The values of Cd in water column of Agboju and Ajegunle, and $\mathrm{Pb}$ recorded from Agboju, Ajegunle and Topo, exceeded the recommended permissible limit of $\mathrm{Cd}$ 
$(0.04 \mathrm{mg} / \mathrm{L})$ and $\mathrm{Pb}(0.003 \mathrm{mg} / \mathrm{L})[16,33-34]$. However, the $\mathrm{Cd}$ recorded in water for this study was lower than that reported in River Benue in Nigeria [35]. In contrast to the present findings, $\mathrm{Cd}$ concentration in surface waters that are within the acceptable limit for drinking water quality has been reported [36-37]. Also, high Cd concentration has been reported by some authors during the rainy season and during dry season respectively [37-38].

Studies have shown that cadmium (Cd) can easily contaminate essential amino acids and accumulates in the proximal tubular cells in higher concentrations and thus causes fragile bones and morphopathological changes in kidney and lung. High Cd could also cause liver dysfunction and neurotoxin, as well as reduced birth weight and premature delivery to pregnant women [39]. The values of $\mathrm{Pb}$ in the water column from Ajegunle, Topo and Agboju which exceeded the standard limit corroborated with other studies that reported $\mathrm{Pb}$ above permissible limits such as in Badagry creek and River Benue [19, 40]. High concentration of $\mathrm{Pb}$ has been reported to be responsible for chronic neurological disorders in infants and children [41]. In this study, the presence of $\mathrm{Fe}, \mathrm{Cu}, \mathrm{Pb} \mathrm{Cr}, \mathrm{Cd}$ and $\mathrm{Zn}$ in the water column is an indication that the aquatic resources in the four aquatic stations are exposed to pollution.

\subsection{Heavy Metals in Ethmalosa Fimbriata}

Spatial and seasonal variation in Ethmalosa fimbriata was recorded only for $\mathrm{Zn}$ and $\mathrm{Fe}$ contents in this study. The values of $\mathrm{Cu}, \mathrm{Zn}$ and $\mathrm{Cr}$ contents in E. fimbriata (from Ajegunle) exceeded the permissible limits of $0.4 \mathrm{mg} / \mathrm{kg}, 5.0 \mathrm{mg} / \mathrm{kg}$ and $0.10 \mathrm{mg} / \mathrm{kg}$ for $\mathrm{Cu}, \mathrm{Zn}$ and $\mathrm{Cr}$ respectively [42]. Similarly, the values of $\mathrm{Pb}$ in the fish from Ajegunle and Agboju were above the permissible limit of $0.29 \mathrm{mg} / \mathrm{kg}$. However, the $\mathrm{Cd}$ and $\mathrm{Fe}$ contents in the fish across the four stations were above permissible limits of $0.002 \mathrm{mg} / \mathrm{kg}$ and $3 \mathrm{mg} / \mathrm{kg}$ for $\mathrm{Cd}$ and $\mathrm{Fe}$ respectively [42]. Similar concentrations of some heavy metals that exceeded the limit in Chrysichthys nigrodigitatus from Ibaka and Ifiayong fishing sites in Akwa Ibom State has been reported [4]. The values of $\mathrm{Pb}, \mathrm{Cr}, \mathrm{Zn}$ and $\mathrm{Cd}$ in this study was higher than that recorded in E. fimbriata from Cross River Estuary [10]. But the values were lower than that reported in Pseudotolithus senegalensis and E. fimbriata from Carter Bridge River and Makoko River in Lagos, Nigeria [43]. The values of metals recorded in fish in this study were also lower than the values reported in Cynothrissa mento from Ologe Lagoon in Lagos Nigeria, in E. fimbriata and Tilapia guineensis from Imo River, in Parachana obscura from Epe Lagoon, in Oreochromis mossambicus from Malir river, Karachi and in Oreochromis niloticus from Asejire creek respectively [6-9, 23]. The value of $\mathrm{Cu}$ in fish for this study was lower than that reported in C. nigrodigitatus [4] from Ibaka and Ifiayong fishing sites in Akwa Ibom State.

Contamination of aquatic habitat with heavy metals like cadmium, lead, copper and chromium has significant health hazard to human beings through food chain [44]. Studies have shown that concentration of cadmium beyond tolerable limits result in reproductive, behavioral, cardiovascular, neurological, hematological, and renal effects, damage of liver, kidney and testicles [45].

Various research studies indicated adverse effects of chromium in fish and such effects include decrease in hemoglobin and total erythrocytes count, thrombocytopenia, decline in proteins, lipids and the contents of glycogen [46].

The clogging action caused by excess iron precipitate hinders the respiration of fishes. The toxicity of iron on human cells has led to iron mediated tissue damage involving cellular reducing and oxidizing mechanism and their toxicity towards intracellular organelles such as lysosomes and mitochondria [47].

Lead toxicity in human causes changes in various biological processes such as cell adhesion, release of neurotransmitters, intra- and inter-cellular signaling, protein folding, maturation, apoptosis, ionic transportation, and enzyme regulation.

Zinc contamination has effect on the hepatic distribution of other trace metals in fish. Its deficiency has been associated with hypogonadism with impaired reproductive capacity, growth retardation, dermatitis, anorexia, and poor wound healing.

Although copper is an essential substance to human life, however, in high concentrations, it can cause intestinal irritation, anemia, liver and kidney damage [48].

\subsection{Heavy Metals in Eichhornia Crassipes}

Only $\mathrm{Fe}$ and $\mathrm{Zn}$ contents in E. crassipes had significant spatial and seasonal variation in this study. The high concentration of iron and zinc in E. crassipes could be attributed to the fact that $\mathrm{Fe}$ and $\mathrm{Zn}$ are abundant in the water bodies. The observed non significant concentrations of $\mathrm{Cd}, \mathrm{Pb}$, $\mathrm{Cr}$ and $\mathrm{Cu}$ in the E. crassipes across the sampling stations could be due to efficient mechanism of elimination by this plant. Studies have shown that E. crassipes have the efficacy to decontaminate soil and water due to its high affinity to accumulate heavy metals in their root systems [49-50]. The level of all the metals detected in E. crassipes across the sampling stations were below WHO recommended limit of metals concentration in plant [51].

\subsection{Heavy Metals Concentration in Sediments}

Only $\mathrm{Fe}, \mathrm{Cu}$ and $\mathrm{Zn}$ show significant spatial and seasonal variation of heavy metals content in the sediment examined from the four sampling stations. The concentrations of these metals were higher in dry season and this could be due to the lower water flow during dry season that may facilitate accumulation of the heavy metals in sediment. Similar seasonal variation was reported in Bonny River, Nigeria [52]. Recommended maximum limits of metals in sediments are: $\mathrm{Fe}(30 \mathrm{mg} / \mathrm{kg}), \mathrm{Pb}(40 \mathrm{mg} / \mathrm{kg}), \mathrm{Zn}(123 \mathrm{mg} / \mathrm{kg}), \mathrm{Cu}(25 \mathrm{mg} / \mathrm{kg})$, $\mathrm{Cr}(20 \mathrm{mg} / \mathrm{kg})$ and $\mathrm{Cd}(0.5 \mathrm{mg} / \mathrm{kg})$ [33] All the heavy metals (except $\mathrm{Fe}$ and $\mathrm{Cd}$ ) in the sediment were below the recommended limit. High concentration of lead and iron could be from automobile emissions, metallic pipes, batteries of pumping equipment and as well as drainage of lead 
compounds from adjacent crop farms treated with agro-chemicals. However, the present of $\mathrm{Fe}$ and $\mathrm{Cd}$ in the sediments above standard limit indicated that the sediment is polluted with Fe and $\mathrm{Cd}$. All the metals in the sediment were lower than that reported in Bonny River, Calabar River and Euphrate River, and in Awoye Estuary in Ilaje Area of Ondo State [52-53]. It is clear that sediments act as the main pool of metals in the aquatic environment. Thus, their quality can indicate the status of water pollution.

\subsection{Evaluation of Contamination in Sediment Using Various Pollution Indices}

The values of contamination factor $(\mathrm{CF})$ in $\mathrm{Cd}$ obtained in sediment from Agboju, Gbaji, Ajegunle and Topo indicated a moderate degree of contamination of sediment with cadmium. However, the $\mathrm{CF}$ values of other metals ( $\mathrm{Fe}, \mathrm{Zn}, \mathrm{Cu}, \mathrm{Pb}$ and $\mathrm{Cr}$ ) across the stations indicated low degree of contamination. This findings was different from the report on Abattoir sediment from PortHarcourt in which the sediment was not contaminated by $\mathrm{Fe}, \mathrm{Cu}, \mathrm{Pb}, \mathrm{Cr}$ and $\mathrm{Cd}$ [54].

All the Igeo values (except that of $\mathrm{Cd}$ ) were within zero category and this indicated that the sediment in this study were practically uncontaminated to moderately contaminated with the metals. On the other hand, Igeo values of $\mathrm{Cd}$ in Ajegunle falls within class 1 and this imply that the sediment were moderately contaminated with lead. All the values for enrichment factors in this study indicated minimal enrichment. In contrast, $\mathrm{EF}$ values of $\mathrm{Pb}, \mathrm{Fe}$ and $\mathrm{Cd}$ that indicated high pollution of sediment was reported from Soku Oil field in Niger Delta [55]. Also, poor enrichment of metals in the sediment of Bonny River has been documented [53].

\section{Conclusion}

The present study has shown that BOD, COD, total hardness and turbidity, $\mathrm{Cd}$ and $\mathrm{Fe}$ contents in the fish across the four stations were above standard permissible limits. This finding indicated that the water bodies have poor quality, with the poorest quality being recorded in Ajegunle. Although, the contamination factor $(\mathrm{CF})$, geoaccumulation index (Igeo) and enrichment index (EF) in sediment across the water bodies indicated low degree of pollution of the water bodies, however, human consumption of several of the fish species examined and the water, especially from Ajegunle creek could lead to $\mathrm{Cd}$ and $\mathrm{Pb}$ biomagnification and eventually could cause $\mathrm{Cd}$ and $\mathrm{Pb}$ related diseases. Therefore, urgent effort should be made by all users of the ecosystem to decline in discharging untreated waste into these water bodies.

\section{References}

[1] Ogundele, O. and Mekuleyi, G. O. (2018). Physico-chemical properties and heavy metals concentration in waste water discharged from two industries in Agbara, Lagos State, Nigeria International Research Journal of Public and Environmental Health, 5 (3): 32-37.
[2] Daniel, E. O., Ugwenze, A. U. and Igbegu, H. E. (2013). Microbiological quality and some heavy metals analysis of smoked fish in Benin city, Edo state, Nigeria. World Journal of Fish and Marine Science. 5 (3): 239-243.

[3] Alinnor, I. J. and Obiji, I. A. (2010). Assessment of trace metal composition in fish samples from Nworie River Pakistan. Pakistan Journal of Nutrition, 9 (1): 81-85.

[4] Akpanyung, E. O., Udoudo, M. E., Ekam, I. A., and Ngozi, O. A. (2014). Levels of heavy metals in fish obtained from two fishing sites in Akwa Ibom State, Nigeria. African Journal of Environmental Science and Technology. 8 (7): 16-21.

[5] Mahboob, S., Kausar, S., Jabeen, F., Sultana, S., Sultana, T., Al-Ghanim, K. A., Hussain, B., Al-Misned, F. and Ahmed, Z., (2016). Effect of Heavy Metals on Liver, Kidney, Gills and Muscles of Cyprinus carpio and Wallago attu inhabited in the Indus. Brazilian Archive Biology and Technology, 59. http://dx.doi.org/10.1590/1678-4324-2016150275.

[6] Kumolu-Johnson, C. A., Ndimele, P. E., Akintola, S. L. and Jibuike, C. C. (2010). Copper, zinc and iron concentrations in water, sediment and Cynothriss amento (Regan 1917) from Ologe Lagoon, Lagos, Nigeria: A preliminary survey. African Journal of Aquatic Science, 35: 87-94.

[7] Monday, U. E. and Nsikak, U. B. (2007). Cadmium, Copper, Lead and Zinc Tissue Levels in Bonga Shad (Ethmalosa fimbriata) and Tilapia (Tilapia guineensis) Caught from Imo River, Nigeria. American Journal of Food Technology, 2 (1): 48-54.

[8] Whenu, O. and Mekuleyi, G. O. (2017). Bioaccumulation of Heavy Metals in the Tissues of African Snakehead (Parachannaobscura) from Epe Lagoon, Lagos, Nigeria. International Journal of Current Science and Studies (IJCSS), $1(1): 1-4$.

[9] Sharmeen, R., Khan, M. Z., Yasmeen, G. and Ghalib, S. A. (2014). Levels of heavy metals (cadmium, chromium, copper, and lead) on water and selected tissues of Oreochromis mossambicus from different locations of Malir River, Karachi. Canadian Journal of Pure and Applied Sciences: 8 (3): 3011-3018.

[10] Udo, I. U. and Ndunobong, E. I (2016). Heavy metal content of two major commercial Fish species of Cross River Estuary, Mbo Local Government Area, Akwa Ibom State, Nigeria. Journal of Aquatic Sciences 31 (2A): 309-317.

[11] American Public Health Association (1998) Standard methods for the examination of water and waste water. 14th edition, Washington DC. Pp: 1007-1157.

[12] Boyd, C. E. (1981). Water Quality in Warm Water Fish Ponds. Agricultural Experimental Station, Auburn University, Alabama, Pages: 358.

[13] Zoller, W. H., Gladney, E. S and Duce, R. A. (1974). Atmospheric concentrations and sources of trace metals at the South Pole. Science, 183: 198-200.

[14] Muller, G. (1969). Index of geoaccumulation in sediments of the Rhine River. Geojournal, 2: 108-118.

[15] DPR (2002). Environmental guidelines and standards for the petroleum industries in Nigeria. Department of Petroleum Resource, Lagos, Nigeria. http://dpr.gov.ng/index/egaspin/. 
[16] WHO (2017). Guidelines for drinking-water quality: fourth edition incorporating the firstaddendum. Geneva: World Health Organization; 2017. Licence: CC BY-NC-SA 3.0IGO.T.

[17] SON (2007). Standards for drinking water quality. Standard Organization of Nigeria, Abuja, Nigeria.

[18] United States Environmental Protection Agency (2002). Methods for measuring the acute toxicity of effluents and receiving waters to freshwater and marine organisms (3rd edn). Washington DC EPA-821-R-02-012.

[19] Aderinola, O. J., Adu, A. A. and Kusemiju, V. (2016). Baseline Study of Surface Water Chemistry of Badagry Creek, Lagos Nigeria. International Journal of Science and Research (IJSR), 5 (4): 843-851.

[20] Edokpayi, C. A., Olowoporoku, A. O and Uwadiae, R. E. (2010). The hydrochemistry and macrobenthic fauna characteristics of an urban draining creek. International Journal of Biodiversity and Conservation, 2 (8): 196-203.

[21] Nwankwo, D. I, Adesalu, T. A, Amako, C. C, Akagha, S. C and Keyede, J. D. (2013). Temporal variations in water chemistry and chlorophyll- $a$ at the Tomaro creek Lagos, Nigeria. Journal of Ecology and Natural Environment, 5 (7): 145-151.

[22] Adesalu, T. A., Bagbe, M. and Keyede, D. (2010). Hydrochemistry and phytoplankton composition of two tidal creeks in south western, Nigeria. International Journal of Tropical Biological, 58: 827-840.

[23] Jenyo-Oni, A. and Oladele A. H. (2016). Heavy Metals Assessment in Water, Sediments and Selected Aquatic Organisms in Lake Asejire, Nigeria. European Scientific Journal, 12: 339-351.

[24] Oladunjoye, R. Y. and Fafioye, O. O. (2016). Biochemical and Physico-Chemical Characterization of Majidun River Water, South-West, Nigeria. International Journal of Environmental Chemistry and Ecotoxicology Research 1 (1): 1-11.

[25] Ndimele, P. E. and Kumolu-Johnson, CA, (2012). Some Aspects of the Physicochemistry and Heavy Metal Content of Water, Sediment and Cynothriss amento (Regan, 1917) from Badagry Creek, Lagos, Nigeria. Trend in Applied Science Research, 7: 724-736.

[26] Ndimele, P. E. (2012). The effects of water hyacinth (Eichhornia crassipes) Infestation on the physic-chemistry, nutrient and heavy metal content of Badagry creek and Ologe Lagoon, Lagos, Nigeria. Journal of Environmental Science and Technology, 5 (2): 128-136.

[27] Loredo, J., Ordonez, A., Galán, M., Fernández-Martínez, R., Alvarez, R., Olay, A., Petit-Domínguez, M., Fernández, R. M., Marín, S., González, M. M. and Rucandio, M. I. (2000). Surface water monitoring in abandoned mercury mine sites in Asturias (Spain): Comparative Studies. $9^{\text {th }}$ International Mine Water Congress, pp. 595-601.

[28] Matthews-Amune, O. C. and Kakulu, S. (2012). Physico-chemical parameters and heavy metals in River Pompom in Okehi Local Government Area of Kogi State, Nigeria. International Research Journal of Biotechnology, 3 (8): 134-140.

[29] Oguntade, O. R., Oketoki, O. T., Ukenye, E. A., Usman, B. A. and Adeleke, M. T. (2014). Survey of the Present and Fast Disappearing Fish Species Along Two Rivers in the Niger Delta. Journal of Fisheries and Aquatic Science, 9: 352-358.
[30] Akintola, S. L., Anetekhai, M. A. and Lawson, E. O. (2011). Some Physicochemical Characteristics of Badagry Creek, Nigeria. West African Journal of Applied Ecology, 18: 95-107.

[31] Akaahan, T. J. A., Araoye, P. A. and Azua, E. T. (2014). Physico-chemical characteristics and macro invertebrates of River Benue at Makurdi, Benue State, Nigeria. International Journal of Science and Technology, 2 (6): 32- 39.

[32] Ekpo, F. E., Agu, N. N. and Udoakpan, U. I. (2013). Influence of heavy metals concentration in three common fish, sediment and water collected within quarry environment, Akampa L. G. area Crossriver State, Nigeria. European Journal of Toxicological Sciences, 3: 1-11.

[33] United States Environmental Protection Agency (USEPA) (2018). Risk assessment, Regional Screening Levels (RSLs) for chemical contaminants at superfund sites-User's guide and summary generic tables.

[34] European Union (2010). European standards for drinking water, 2 edition, World HealthOrganisaion, Switzerland, 3-35.

[35] Akaahan, T. J. A., Olabanji, F. M. and Azua, E. T. (2015). Studies on contamination of surface waters of river Benue with trace elements at Makurdi, Benue State, Nigeria. Journal of Environmental Chemistry and Ecotoxicology, 7 (5): 49-55.

[36] Sanusi, K. A., Hassan, M. S., Abbas, M. A. and Kura, A. M. (2017). Assessment of heavy metals contamination of soil and water around abandoned $\mathrm{Pb}-\mathrm{Zn}$ mines in Yelu, Alkaleri Local Government Area of Bauchi State, Nigeria. International Research Journal of Public and Environmental Health, 4 (5): 72-77.

[37] Abah, J., Ubwa, S. T., Onyejepu, D. I. and Nomor, S. A. (2013) Assessment of some trace metals content of Oreochromisnilolicusobtained from River Okpokwu, Apa, Benue State Nigeria. Research Journal of Chemical Sciences, 3 (3): 70-75.

[38] Olatunji, O. S. and Osibanjo, O. (2012). Determination of selected heavy metals in inland fresh water of lower River Niger drainage in North Central Nigeria. African Journal of Environmental Science and Technology, 6 (10): 403-408.

[39] Adelekan, B. A. and Alawode, A. O. (2011). Contributions of municipal refuse dumps to heavy metals concentrations in soil profile and groundwater in Ibadan Nigeria. Journal of Applied Biosciences, 40: 2727-2737.

[40] Hong, A. H., Law, P. L. and Selaman, O. S. (2014). Physico chemical quality assessment of pollutants in River Benue water in Jimeta/Yola Metropolitan. Adamawa State North Eastern Nigeria. American Journal of Environmental Protection, 3 (2): 90-95.

[41] Lawson, E. O. (2011). Physico-Chemical Parameters and Heavy Metal Contents of Water from the Mangrove Swamps of Lagos Lagoon, Lagos, Nigeria. Biological Resources, 5 (1): 8-21.

[42] FAO/WHO (2011). Joint FAO/WHO food standardsprogramme codex committee on contaminants in foods. 5th Session, The Hague Netherlands, 21-25 March, 2011, ftp://ftp.fao.org/codex/meetings/CCCF/cccf5/cf05_INF.pdf.

[43] Bolawa, O. E. and Gbenle, G. O. (2012) Physiochemical parameters and metallic constituents of Makoko, Maroko and Carter bridge rivers in Lagos, Nigeria. Instasci. Journal of Chemistry, 2 (2): 56-63. 
[44] Krishna, P. V., Jyothirmayi, V. and Madhysydhana, R. K. (2014). Human health risk assessment of heavy metal accumulation through fish consumption from Machilipatnan Coast, Andhra Pradesh, India. International Research Journal of Public and Environmental. Health, 1 (5): 121-125.

[45] Hanser, R. and Marrion, H. (2009). Articles on natural medicine, "The dangers of heavy metals. Environmental Health Perspectives, 89: 91-94.

[46] Sonia, A. and Ali, M. Y. (2017). Chromium toxicity in fish: A review article. Journal of Entomology and Zoology Studies, 5 (3): 1483-1488.

[47] Albretsen J. (2006). The toxicity of iron, an essential element. Veterinary medicine, 82-90.

[48] Tepe Y, (2014). Toxic Metals: Trace Metals - Chromium, Nickel, Copper, and Aluminum, In Encyclopedia of Food Safety, edited by Yasmine Motarjemi,, Academic Press, Waltham, Pp 356-362.

[49] Bolan, N. S., Park, J. H., Robinson, B., Naidu, R. and Huh, K. Y. (2011). Phytostabilization: a green approach to contaminant. Advances in Agronomy, 112: 145-204.

[50] Sudharshi, W. and Chandramali, K. J. (2018). Potential of Aquatic Macrophytes Eichhornia crassipes, Pistia stratiotes and Salvinia molesta in Phytoremediation of Textile Waste water. Journal of Water Security, 4: 1-8.

[51] Chiroma, T. M., Ebewele, T. O. and Hymore, F. K. (2012). Levels of Heavy Metals $(\mathrm{Cu}, \mathrm{Zn}, \mathrm{Pb}, \mathrm{Fe}$ and $\mathrm{Cr}$ ) in Bushgreen and Roselle Irrigated with Treated and Untreated Urban Sewage Water. International Research Journal of Environmental Sciences, 1 (4): 50-55.

[52] Bubu, A., Ononugbo, C. P. and Avwiri, G. O. (2017). Determination of Heavy Metal Concentrations in Sediment of Bonny River, Nigeria. Archives of Current Research International 11 (4): 1-11.

[53] Adesina, R. B. and Ogunseiju, P. (2017). An Assessment of Bathymetry, Hydrochemistry and Trace Metals in Sediments of Awoye Estuary in Ilaje Area, Southwestern Nigeria. Journal of Geosciences and Geomatics 5 (2): 78-86.

[54] Edori, O. S. and Kpee, F. (2016). Index Models Assessment of Heavy Metal Pollution in Soils within Selected Abattoirs in Port Harcourt, Rivers State, Nigeria. Singapore Journal of Scientific Research, 7: 9-15.

[55] Olu, U., Ugbomeh, A. P., Bob, M. K. N. O. and Ekweozor, I. (2019) Levels of Selected Heavy Metals in Water and Sediment of the Soku Oil Field Area of the Niger Delta, Nigeria. Journal of Aquatic Pollution and Toxicology, 3 (1, 25): 1-9. 